

\title{
Family Relationships and Youth Sport: Influence of Siblings and Parents on Youth's Participation, Interests, and Skills
}

\author{
Keith V. Osai
}

Shawn D. Whiteman

\section{Utah State University}

Taking a family systems perspective, the present study investigated how older siblings' and parents' (mothers' and fathers') self-reported interests, skills, and participation in sports predicted younger siblings' attitudes and behaviors in those same domains. Testing social learning principles, we further examined whether family members' influence was stronger when they shared warmer relationships and siblings shared the same gender. Participants included mothers, fathers, and adolescent-aged first and second-born siblings from 197 maritally intact families. Families participated in home interviews as well as a series of 7 nightly phone calls during which participants reported on their daily activities. Across dependent variables, results revealed that parents' and (with one exception) older siblings' qualities were predictive of younger siblings' interests, skills, and participation in sports. Inconsistent with hypotheses, however, family members' influence was not moderated by relational warmth. Discussion highlights the need to examine the socialization processes by which siblings shape each other's sport-related attitudes and activities.

$\mathrm{T}$ o date, most research on youth sport has focused on parent involvement, socialization, and influence (e.g.,

Coakley, 2006; Fraser-Thomas, Côté, \&

Deakin, 2005; Knight, Dorsch, Osai, Haderlie, \& Sellars, 2016; Ullrich-French \& Smith, 2006). Yet, consistent with a family systems perspective (e.g., Cox \& Paley, 1997), in that multiple family relationships should be examined in order to gain a better understanding of the phenomena being studied, scholars have called for further investigation into the role that siblings play in shaping youth's interests and 
participation in sports (Blazo, Czech, Carson, \& Dees, 2014; Côté \& Hay, 2002; Davis \& Meyer, 2008; Trussell, 2014). In fact, a recent systematic review of the literature highlighted the need to further explore this close familial relationship within the context of youth sport (Blazo \& Smith, 2017). The present study addressed this gap, specifically exploring how mothers', fathers', and older siblings' interests, skills, and participation in sportrelated activities were related to younger siblings' attitudes and behaviors in those same domains.

\section{Sibling Influence during Adolescence}

Sibling relationships are generally the most enduring family relationship that individuals will experience (Cicirelli, 1995; Conger \& Kramer, 2010; Whiteman, McHale \& Soli, 2011). Further, siblings are omnipresent during childhood and adolescence. For example, about $82 \%$ of youth, 18 years and younger, lived with a sibling (as compared to 78\% who lived with a father; McHale, Updegraff, \& Whiteman, 2012). Research also notes that during middle childhood and early adolescence, outside of school, siblings spend more time with each other as opposed to other relational partners (Larson \& Richards, 1994; McHale \& Crouter, 1996; Updegraff, McHale, Whiteman, Thayer, \& Delgado, 2005).

Given their ubiquity during childhood and adolescence, it is not surprising that siblings' attributes, attitudes, and behaviors shape their brothers' and sisters' well-being and health-related adjustment. For example, research both outside and inside of the sport context reveals that siblings have the potential to influence each other by serving as role models or rivals (Blazo et al., 2014; Davis \& Meyer, 2008; Ebihara, Ikeda, \& Myiashita, 1983; Whiteman, McHale, \& Crouter, 2007). To date, most literature on sibling similarities has explored social learning explanations, holding that younger siblings learn from observing and imitating their older brothers' and sisters' behaviors. In fact, older siblings are especially powerful models from which younger siblings can learn from because they often possess characteristics that Bandura (1977) noted of effective models, namely higher status, nurturance, and similarity. Testing these notions, research on adolescents' risky and health-related behaviors has explored how sibling relationship factors like similarity (i.e., age difference, gender composition) and nurturance (i.e., warmth and social connectedness) moderate similarities between siblings' attributes and behaviors. For example, studies of substance use and delinquency find greater similarities between closer-aged and same-gendered siblings than wider-spaced or mixed-gendered siblings, respectively (Kendler, Ohlsson, Sundquist, \& Sundquist, 2013; Slomkowski, Rende, Conger, Simons, \& Conger, 2001). Similarly, siblings who share warmer relationships and more social connectedness displayed more similar patterns of delinquency, substance use, and sexual risk behaviors than siblings 
who had more distant relationships (McHale, Bissell, \& Kim, 2009; Rowe \& Gulley, 1992; Slomkowski, Rende, Novak, Lloyd-Richardson, \& Niaura, 2005).

While research regarding sibling modeling continues to be empirically tested outside of youth sport, research within youth sport has focused on sibling similarities and differences without explicitly testing mechanisms that may shape these patterns (Blazo \& Smith, 2017). This omission is striking, given youth reports that siblings provide emotional support and serve as role models within the context of sport (Blazo et al., 2014; Davis \& Meyer, 2008; Fraser-Thomas, Côté \& Deakin, 2008; Nelson \& Strachan, 2017; Trussell, 2014).

In addition to serving as potential models, research on youth sport has identified other ways in which older siblings may shape their younger brothers' and sisters' behaviors. For example, siblings have also been identified as sources of competition, resentment, and jealousy (Blazo et al., 2014; Côté, 1999; Nelson \& Strachan, 2017). Further, recent work on performance outcomes between siblings highlights findings that younger siblings achieve higher athletic status compared to older siblings (Hopwood, Farrow, MacMahon, \& Baker, 2015). While not explicitly tested or found, these results point to a next step to test whether or not older siblings serve as role models in sport-related activities. Whether the athlete uses their sibling as a role model or rival, both roads have the potential to lead to continued sport participation or dropout.

\section{The Present Study}

When using a family systems framework to examine sibling relationships, researchers must not only focus on each family relationship and how they act as interdependent parts of the family system, but also how permeable the boundaries are between those relationships (Cox \& Paley, 1997; Smith \& Hamon, 2012). Additionally, unique to sibling and other family relationships, is the concept of hierarchy, in that those who rank higher in power generally have more influence (Smith \& Hamon). In the present study, consistent with this idea and past research on parent socialization and sibling influence, we maintained a vertical or top-down view of socialization, such that parents and older siblings will socialize/influence younger siblings' self-reported interests, skills, and participation in sport.

Given that approximately $90 \%$ of all youth participate in organized youth sport (Jellinek \& Durrant, 2004) and the large majority of youth grow up in homes with siblings (McHale et al., 2012), it is critical that research explore how siblings, in addition to parents, shape each other's sports-related interests and activities. The present study addressed this gap in the youth sport literature by examining how older siblings' self-reported interests, skills, and participation in sports-related activities were related to their younger siblings' self- 
reported interests, skills, and participation in those same activities. Taking a family systems perspective, we also included mothers' and fathers' self-reported interests, skills, and participation in sports-related activities in our models to test for potential unique effects of each relational partner. Furthermore, we tested two social learning principles. First, testing the notion that relational partners (or models) who share warm and intimate relationships are more likely to be imitated, we examined whether relational intimacy moderated the association between family members' (i.e., siblings', mothers', and fathers') interests/skills/participation in sportsrelated activities and younger siblings' interests/skills/participation in those same domains. Second, investigating the idea that models that are more similar (e.g., same gender) to the target are more likely to be imitated, we tested whether gender composition moderated the association between older and younger siblings' interests/skills/participation in sportsrelated activities.

\section{Methods}

\section{Participants}

Data were drawn from a study of family relationships that focused on intact (i.e., two residential parents) families with at least two-adolescent aged offspring. Specifically, the participants included mothers $(M=$ 39.84, $S D=3.92$, range $=31.83-50.17$, years of age), fathers $(M=41.80, S D=$ 4.23 , range $=32.92-57.92$, years of age $)$, first- $(M=14.96, S D=.71$, range $=13.08-$ 16.50 , years of age), and second-born $(M=$ $12.49, S D=1.02$, range $=10.00-14.83$, years of age) offspring from 197 families. The sibling dyads were divided almost equally among the four possible gender constellations (23\% older sisters/younger sisters; $22 \%$ older sisters/younger brothers; $27 \%$ older brothers/younger sisters, $27 \%$ older brothers/younger brothers). Approximately, $44 \%$ of families had children younger than the second-born.

Families were recruited through letters sent home with $8^{\text {th }}, 9^{\text {th }}$, and $10^{\text {th }}$ graders in 18 school districts throughout the central part of a northeastern state. The school districts were generally small in size (on average, about 200 students per grade) and served the rural communities and small cities of the region. Families were informed that the researchers were interested in studying the challenges of rearing children in contemporary US society. Interested families returned a postcard to the project and were contacted by phone to confirm whether they fit the criteria for participation: that parents were not divorced and that the family included two siblings in the targeted age range. This recruitment strategy meant that we did not have a count of how many families meeting our criteria failed to volunteer. Of those families who returned postcards to us and who met our criteria, however, more than 90 percent agreed to participate.

Reflecting the demographics of the small towns, cities, and rural areas where 
they resided, families were almost exclusively White (98\%) and working and middle class (annual family income, $M=$ $\$ 62,951, S D=\$ 39,3313, M d n=\$ 56,600$, range $=\$ 13,400-\$ 400,000)$. In these families, less than $2 \%$ of mothers and fathers had not completed high school, 37\% of fathers and $32 \%$ of mothers stopped their education after high school, $26 \%$ of fathers and mothers completed some college, $36 \%$ of fathers and $41 \%$ of mothers were college graduates or had graduate or professional degrees.

\section{Procedures}

Two data collection procedures were employed. First, home interviews that averaged between two and three hours in duration were conducted with mothers, fathers, and both first- and second-born offspring on the same day. Informed consent/assent was obtained from each family member prior to the interview. Then, family members participated separately in semi-structured interviews and completed individually administered questionnaires. For their participation, families received an honorarium of $\$ 100$.

Second, during the two to four-week period following the home interviews, a series of seven evening telephone interviews was also conducted (five call on weekdays, two calls on weekends). The telephone interviews focused on family members' involvement in daily activities (e.g., chores and leisure), including how long each activity lasted and who else participated in that activity (e.g., siblings, parents, and friends).

\section{Measures}

Demographic Information. Family background information, including parents' age, education, income, family size, and offspring characteristics such as age, birth order, and gender were obtained from parents. Siblings' gender $(0=$ female, $1=$ male) and gender composition of the sibling dyad $(0=$ same-gender dyad, $1=$ mixedgender dyad) were dummy coded.

Sibling Intimacy. Intimacy in the sibling relationship was rated by both firstand second-born siblings using an eightitem questionnaire developed by Blyth and Foster-Clark (1987). On a scale ranging from 1 ("not at all") to 5 ("very much"), youth rated their experiences with their siblings. Example items included: "How much do you go to your brother/sister for advice/support?" "How much do you share your inner feelings or secrets with your brother/sister?" And, "How much does your sister/brother understand what you are really like?" Scores were summed across the eight items (i.e., potential range of scores $=8$ - 40), with higher scores denoting greater intimacy. For the present study, we utilized younger siblings' reports of intimacy ( $M=$ 23.89, $S D=5.99$, Cronbach's $\alpha=.85$ ).

\section{Parent-Adolescent Intimacy.}

Intimacy with both mothers and fathers was rated by both siblings separately, using the same eight-item relational intimacy questionnaire developed by Blyth and 
Foster-Clark (1987). Targets for the items were changed to reflect interest in parentadolescent intimacy (e.g., "How much do you go to your mother/father for advice/support?"). Scores were summed across the items (i.e., potential range of scores $=8-40$ ), with higher scores denoting greater relational intimacy. For the present study, we focused on younger siblings' reports of intimacy with their mothers $(M=30.32, S D=4.80$, Cronbach's $\alpha=.82)$ and fathers $(M=28.57, S D=4.53$, Cronbach's $\alpha=.79$ ).

\section{Sport-Related Interests and Skills.}

Parents' and youth's interests and skills in sport-related activities were assessed using a measure developed by Huston, McHale, and Crouter (1985). Specifically, on a scale from 1 ("not at all") to 4 ("very"), parents' and youth rated how interested they were in and skillful in performing 31 different activities (e.g., sports, computer games, arts, writing, cooking, religious activities). Sports-related interests and skills were assessed from a single "sports" item that included baseball, football, basketball, soccer, skiing, softball, volleyball, and tennis as examples. Interests and skills in sports were rated separately. Higher scores denote greater interest/skill in performing sport-related activities. In general, participants reported moderate to strong interests in sports $(M=3.02, S D=$ 1.09 for mothers; $M=3.53, S D=.78$ for fathers; $M=3.54, S D=.75$ for firstborns; $M=3.52, S D=.84$ for second-borns) and moderate skillfulness $(M=2.13, S D=.89$ for mothers; $M=2.98, S D=.80$ for fathers; $M=3.21, S D=.82$ for firstborns; $M=3.30, S D=.85$ for second-borns).

\section{Participation in Sports-Related}

Activities. Parents' and youth's time spent in sports related activities were assessed using data collected in the telephone interviews. Specifically, in each call, participants reported how much time (in minutes) they spent on sports (i.e., baseball, football, basketball, soccer, skiing, softball, volleyball, or tennis). Time spent was then aggregated across the seven telephone interviews to index how much time they spent in a typical week. Higher scores denote greater time spent on sport-related activities $(M=8.48, S D=32.16$ minutes $/ 7$ days for mothers; $M=26.62, S D=69.55$ minutes $/ 7$ days for fathers; $M=162.41, S D$ $=223.43$ minutes $/ 7$ days for firstborns; $M$ $=151.10, S D=201.21$ minutes $/ 7$ days for second-borns).

\section{Analytic Strategy}

To address our study goals, we performed a series of hierarchical multiple regressions. Models were run separately for each dependent variable (i.e., interests, skills, and participation in sports-related activities separately). To test whether older siblings were a unique source of influence, above and beyond parents, our initial (main effects) models included effects for youth gender $(0=$ female, $1=$ male $)$, gender composition of the sibling dyad $(0=$ samegender dyads, 1 = mixed-gender dyads), mothers', fathers', and older siblings' interests/skills/participation in sports- 
related activities as well as main effects for mother-adolescent intimacy, fatheradolescent intimacy, and sibling intimacy. Each of the aforementioned continuous variables were centered at the sample mean. To test whether maternal, paternal, or sibling influences were stronger when they shared a warmer (or more intimate) relationship, our second model included interaction terms between each family members' interests/skills/participation in sports-related activities and younger siblings' reports of intimacy with each partner. For each dependent variable, an additional interaction term between older siblings' interests/skills/participation in sports-related activities and gender composition was included to test whether sibling influence was stronger for samegender as opposed to mixed-gender dyads. Significant interactions were probed following the procedures outlined by Aiken and West (1991).

\section{Results}

\section{Interests in Sports}

The initial model for youth's interests in sports revealed several significant main effects (see Table 1). First, a main effect for gender revealed that boys had significantly higher interests in sports-related activities than girls. Second, a positive main effect for sibling intimacy revealed that second-born siblings with warmer sibling relationships reported greater interests in sports-related activities. Finally, mothers' interests in sports were positively related to second- born siblings' interests. Neither fathers' or older siblings' interests were significantly associated with second-born siblings' interests. In model 2, there were no significant interactions between family members' interests in sports and relational intimacy with each partner, or between older siblings' interests and gender composition of the sibling dyad.

\section{Skills in Sports}

Similarly to interests, the initial model for youth's sports-related skills revealed several significant main effects (see Table 2). First, a main effect for gender revealed that boys reported significantly higher skills in sports-related activities than girls. Second, a positive main effect for sibling intimacy revealed that second-born siblings with warmer sibling relationships reported greater sports-related skills. Finally, both fathers' and older siblings' skills were positively associated with second-born siblings' self-reported skills. In model 2, there were no significant interactions between family members' sports-related skills and relational intimacy with each partner, or between older siblings' skills and gender composition of the sibling dyad.

\section{Participation in Sports}

The initial model for youth's participation in sports-related activities revealed two main effects (see left side of Table 3). First, a main effect for gender revealed that boys spent more time in sportrelated activities over the course of seven 
days than did girls. Second, a main effect of older siblings' participation in sports-related activities revealed that older siblings' participation was positively associated with younger siblings' participation. In model 2, there were no significant interactions between family members' sports-related participation and relational intimacy with each partner. However, there was a significant interaction between older siblings' participation and gender composition (see right side of Table 3). As can be seen in Figure 1, analysis of the simple slopes revealed that older siblings' time spent in sports-related activities was strongly related to younger siblings' time spent in sports-related activities for samegendered sibling $(b=.44, S E=.09, p<$ $.001, \beta=.49)$, but unrelated for mixed gendered siblings $(b=.06, S E=.09, n s, \beta=$ $.06)$.

\section{Discussion}

Following recent calls to examine the ways in which siblings shape each other's interest and participation in sport (e.g., Blazo \& Smith, 2017), the present study investigated whether older siblings' interests/skills/participation in sports uniquely predicted their younger brothers' and sisters' interests/skills/participation above and beyond the influence of parents. Advancing the literature of youth sport, we further explored an important, and understudied, component of sibling socialization. Testing social learning principles, we specifically investigated whether older siblings' (and parents') influence would be stronger when they shared warmer/more intimate relationships and if siblings shared the same gender.

\section{Interests in Sports}

Results indicated that boys expressed greater interests in sports than girls. While this is consistent with gender differences in participation (NCYS, 2008), such that boys tend to participate in more sport than girls, it is important for future research to monitor given the rising participation of girls in youth sport. In fact, given the changing contexts of sport participation, as more girls participate in youth sport, and become prominent figures while serving as role models for their sisters (Nelson \& Strachan, 2017), future research would benefit from further exploration of sport participating older sisters' influence on younger sisters' interests in sports.

Consistent with research on mothers' influence on child interests' in sport (Weiss \& Barber, 1995) and the concept of hierarchy within the family system, our results showed that mothers' interests uniquely predicted younger siblings' interests in sports. When considered in combination with the fact that mothers' less frequently participated in sports than fathers or older siblings, this finding may reflect mothers' roles as gatekeepers and managers of their children's activities (Clarke-Stewart \& Parke, 2014; Grusec, Chaparro, Johnston \& Sherman, 2013; Huston \& Ripke, 2006). This notion of mothers' control of 
children's environments also helps explain why fathers' and older siblings' were not significant influences on second-born siblings' interests in sports.

\section{Skills in Sports}

Similar to the results for interests, boys reported higher levels of skills in sports than girls did. Perhaps boys greater level of involvement in youth sport (NCYS, 2008) results in more experience and possibly higher expectations for skill level. Further, it follows that those who have a greater interest in sport are more likely to practice and gain more skill. Youth who reported warmer sibling relationships also reported greater sports-related skills. It could be that warmer sibling relationships promote a context in which sports-related skills can be practiced and enhanced. However, as we discuss later, we did not find evidence that warmer relationships enhanced older siblings' effects.

Contrary to interests, fathers' and older siblings' skills in sports, but not mothers' skills, were positively associated with younger siblings' skills. Given that fathers are more involved in play and interactive activities with their offspring (e.g., McBride \& Mills, 1993; Robinson \& Godbey, 1997), the former finding could reflect fathers' direct involvement in promoting their children's skills. Further, with increasing societal expectations of parents to constantly monitor their children, youth sports may be a natural home where fathers feel comfortable being involved (Coakley,
2006). Importantly, older siblings' perception of sports-related skills was the strongest predictor of younger siblings' skills. Given the shared time that siblings spend together in childhood and adolescence (McHale \& Crouter, 1996; Updegraff et al., 2005), siblings likely provide each other with partners to engage in and enhance their sports skills and abilities. Further, given that sibling relationships include elements of complementarity like parent-child relationships as well as reciprocity like peer relationships (Dunn, 1983), older siblings may serve as particularly important socialization agents.

\section{Participation in Sports}

Similar to both interests and skills in sport, boys spent more time playing sports than girls did. Taken together, it could be that boys greater interests in sports leads to more participation, which in turn, gives youth the opportunity to practice/play more, thus increasing their skills. Unfortunately, our cross-sectional data cannot disaggregate such temporal patterns, but future longitudinal research should consider how youth's interests shape their later participation and skills.

Older siblings' participation in sportrelated activities was also positively associated with younger siblings' time spent in sports. Importantly, however, this effect was moderated by an interaction with gender composition of the sibling dyad. Findings revealed that older siblings' 
participation was only associated with younger siblings' participation in samegender dyads. This finding is consistent with previous research on physical activity and the socialization of sport, in that samegendered siblings were found to be influential with continued sport participation (Ebihara, Ikeda, \& Myashita, 1983; Ziviani, Macdonale, Ward, Jenkins, \& Rodgers, 2006). This finding may also reflect that same-gendered siblings (especially, sister-sister dyads) spend more time in various activities during adolescence as compared to mixed-gender siblings (Updegraff et al., 2005).

\section{Limitations}

The results of the present study should be considered in context of its' limitations. First, inconsistent with hypotheses, we did not find evidence that relational warmth moderated the associations between family members' interests, skills, and participation in sports. Although used in previous research as a proxy for modeling (e.g., McHale et al., 2009; Slomkowski et al., 2005), it could be that relational intimacy is not an adequate measure of social learning. Indeed, work by Whiteman and colleagues (e.g., Whiteman, Bernard, \& McHale, 2010; Whiteman, Jensen, \& Maggs, 2013; Whiteman, McHale, \& Crouter, 2007) shows that newer measures of social learning predict similarities above and beyond relational intimacy. Additionally, rather than similarities in siblings' behavior/development being influenced and moderated by relational warmth, patterns may be better explained by the concept of triadic reciprocal determinism (Bandura, 1989). This extension of social learning theory suggests that individual development is predicated upon the reciprocal interaction of person/cognitive factors, the environment, and behavior. Therefore, future research should consider how individuals' biological characteristics and belief in oneself (person/cognitive factors), perceptions of and actual sports environment (including siblings), and behavior, all interact to influence youth in sport.

Second, the ability to generalize the findings is limited due to the homogenous racial make-up of the participants. Families of different ethnicities may demonstrate varying levels of sibling influence. For example, sibling influence may be greater in families that emphasize familism or those in which siblings provide a great deal of caretaking. Additionally, this study only examined youth from two-parent, martially intact families. Future research should explore how parents and siblings, including step-siblings, shape youth's interests and participation in sports in single-parent and remarried families. In fact, given differences in parental time and resources, it could be that sibling influences are stronger in singleparent families.

Third, although this study controlled for birth order effects by only including firstand second-born siblings, it ignored the potential influence of additional younger 
siblings. Future research on sibling relationships should include all members of the family to understand how all family subsystems interact to shape youth's interests and behaviors. Additionally, given our relatively small sample, we explored whether the associations between siblings' interests, skills, and participation in sports were greater in same- as opposed to mixedgender dyads. As mentioned earlier, given the changing demographics of sports participation, future research with larger samples should explore whether patterns of sibling influence are stronger in dyads involving only sisters, brothers, or various combinations.

Fourth, although we used multiple methods and reporters, our measures of interests, skills, and participation were based on a single category of sports that included several potential sub-dimensions. Future work should make greater distinctions between youth's interests, skills, and participation in specific sports, and determine whether family socialization operates in general or domain specific patterns.

Fifth, because of our cross-sectional design, were unable to test whether older siblings' qualities were related to changes in younger siblings' qualities over time. Sibling relationships are dynamic, particularly in adolescence (e.g., Kim, McHale, Osgood, \& Crouter, 2006; Whiteman, Solmeyer, \& McHale, 2015), and thus, their influence on one another may fluctuate as a function of developmental period. Longitudinal assessments are critical to study such possibilities. Finally, consistent with models of parent socialization during adolescence (Smetana, Robinson, \& Rote, 2015) and most research on sibling influences, we followed a vertical or top-down socialization perspective. That is, we viewed socialization as flowing downward from older (parents, older siblings) to younger family members. In addition to hierarchy, a family systems perspective (Cox \& Paley, 1997) highlights the multidirectionality of family processes. Such possibilities may be especially likely in sibling relationships given their more egalitarian role structures. Future research, with longitudinal designs should explore potential bidirectional/reciprocal effects within families, especially siblings.

\section{Future Directions}

Future work including siblings, sibling relationships, and sibling socialization represents an important direction for the youth sport literature. For example, similar to the literature of health risk behaviors, greater emphasis should be placed on the mechanisms of sibling influence during childhood and adolescence. In addition to studying social learning processes such as modeling and imitation, researchers can add to this literature by examining how sibling rivalry and deidentification (or differentiation) processes shape youth's interests and participation in sport. For example, qualitative research highlights that sibling competition and rivalry are associated with discontinuation of sport 
(Fraser-Thomas, Côté, \& Deakin, 2008). By testing mechanisms of sibling influence, future research has the opportunity to illuminate how siblings and entire family systems shape youth's engagement in sport. 


\section{References}

Aiken, L. S., \& West, S. G. (1991). Multiple regression: Testing and interpreting interactions. Thousand Oaks, CA: Sage.

Bandura, A. (1977). Social learning theory. Englewood Cliffs, NJ: Prentice Hall. Bandura, A. (1989). Social cognitive theory. In R. Vasta (Ed.), Six theories of child development. Annual Review of Clinical Psychology, 6, (p1-60) Greenwich, CT: JAI Press.

Blazo, J. A. \& Smith, A. L. (2017). A systematic review of siblings and physical activity experiences.

International Review of Sport and Exercise Psychology. doi: 10.1080/1750984X.2016.1229355.

Blazo, J. A., Czech, D., Carson, S., \& Dees, W. (2014). A qualitative investigation of the sibling sport achievement experience. The Sport Psychologist, 28, 36-47. doi:

http://dx.doi.org/10.1123/tsp.20120089

Blyth, D. A., \& Foster-Clark, F. S. (1987). Gender differences in perceived intimacy with different members of adolescents' social networks. Sex Roles, 17, 689-718. doi: 10.1007/BF00287683

Cicirelli, V. G. (1995). Sibling relationships across the life span. New York: Plenum Press.

Clarke-Stewart, A. K. \& Parke, R. D. (2014). Social Development (2 ${ }^{\text {nd }}$ ed.). New York: Wiley.
Coakley, J. (2006). The good father: Parental expectations and youth sports. Leisure Studies, 25 (2), 153-163. doi: $10.1080 / 02614360500467735$.

Conger, K. J., \& Kramer, L. (2010). Introduction to the special section: Perspectives on sibling relationships: Advancing child development research. Child Development Perspectives, 4, 69-71. doi: 10.1111/j.17508606.2010.00120.x

Côté, J. (1999) The influence of the family in the development of talent in sport. The Sport Psychologist, 13, 395-417. doi: 10.1123/tsp.13.4.395

Côté, J. \& Hay, J. (2002). Family influences on youth sport performance and participation. In J. Silva \& D. Stevens (Eds.), Psychological foundations of sport (p. 503-519). Boston, MA: Allyn \& Bacon.

Cox, M. J., \& Paley, B. (1997). Families as systems. Annual Review of Psychology, 48, 243-267. doi: 10.1146/annurev.psych.48.1.243

Davis, N. W. \& Meyer, B. B, (2008) When sibling becomes competitor: A qualitative investigation of same-sex sibling competition in elite sport. Journal of Applied Sport Psychology, 20, 220-235. doi: 10.1080/10413200701864817

Dunn, J. (1983). Sibling relationships in early childhood. Child Development, 54, 787-811. doi:10.2307/1129886

Ebihara, O., Ikeda, M., \& Myiashita, M. (1983). Birth order and children's 
socialization into sport. International Review for the Sociology of Sport, 18, 6990. doi: 10.1177/101269028301800305

Fraser-Thomas, J. L., Côté, J. \& Deakin, J. (2005). Youth sport programs: An avenue to foster positive youth development, Physical Education and Sport Pedagogy, 10, 19-40. doi: 10.1080/1740898042000334890.

Fraser-Thomas, J., Côté, J., \& Deakin, J. (2008). Understanding dropout and prolonged engagement in adolescent competitive sport. Psychology of Sport and Exercise, 9, 645-662. doi: 10.1016/j.psychsport.2007.08.003 Grusec, J. E., Chaparro, M. P., Johnston, M., \& Sherman, A. (2013). Social development and social relationships in middle childhood. In I.B. Weiner et al. (Eds.), Handbook of moral development $\left(2^{\text {nd }}\right.$ ed., $\left.\mathrm{Vol}\right)$. New York: Wiley.

Hopwood, M. J., Farrow, D., MacMahon, C., \& Baker, J. (2015). Sibling dynamics and sport expertise. Scandinavian Journal of Medicine \& Science in Sports, 25, 724-733. doi: $10.1111 /$ sms. 12387

Huston, T. L., McHale, S. M., \& Crouter, A. C. (1985). Changes in marital relationship during the first year of marriage. In R. Gilmour \& S. Duck (Eds.), The emerging field of personal relationships (pp. 109-132). Hillsdale, NJ: Erlbaum.
Huston, A. C., \& Ripke, M. N. (2006). Experiences in middle and late childhood and children's development. In Huston A. C. \& Ripke, M. N. (Eds.), Development contexts in middle childhood. New York: Cambridge University Press. Jellinek, M., \& Durant, S. (2004). Parents and sports: Too much of a good thing? Contemporary Pediatrics, 21, 1720.

Kendler, K. S., Ohlsson, H., Sundquist, K., \& Sundquist, J. (2013). Within-family environmental transmission of drug abuse: a Swedish national study. JAMA Psychiatry, 70, 235-242. doi:10.1001/jamapsychiatry.2013.276

Kim, J. Y., McHale, S. M., Osgood, D. W., \& Crouter, A. C. (2006). Longitudinal course and family correlates of sibling relationships from childhood through adolescence. Child Development, 77, 1746-1761. doi:10.1111/j.14678624.2006.00971.x

Knight, C. J., Dorsch, T. E., Osai, K. V., Haderlie, K. L., \& Sellars, P. A. (2016). Influences on parental involvement in youth sport. Sport, Exercise, and Performance Psychology, 5, 161-178. http://dx.doi.org/10.1037/spy00000 53.

Larson, R., \& Richards, M. H. (1994). Divergent realities: The emotional lives of mothers, fathers, and adolescents. New York: Basic Books. 
McBride, B. A., \& Mills, G. (1993). A comparison of mother and father involvement with their preschool age children. Early Childhood Research Quarterly, 8, 457-477. doi:10.1016/S0885-2006(05)80080-8

McHale, S. M., Bissell, J., Kim, J. (2009). Sibling relationship, family, and genetic factors in sibling similarity in sexual risk. Journal of Family Psychology. 23, 562-572. doi:10.1037/a0014982.

McHale, S. M., \& Crouter, A. C. (1996). The family contexts of children's sibling relationships. In G. Brody (Ed.), Sibling relationships: Their Causes and Consequences (p. 173-195). Norwood, NJ: Ablex.

McHale, S. M., Updegraff, K. A., \& Whiteman, S. D. (2012). Sibling relationships and influences in childhood and adolescence. Journal of Marriage and Family, 74, 913-930. doi: 10.1111/j.1741-3737.2012.01011.x

National Council of Youth Sport. (2008). Reports on trends and participation in youth sports. Retrieved from http://www.ncys.org/pdfs/2008/20 08-ncys-market-research-report.pdf.

Nelson, K., \& Strachan, L. (2017). Friend, foe, or both? A retrospective exploration of sibling relationships in elite youth sport. International Journal of Sports Science \& Coaching, 12, 207-218. doi: 10.1177/1747954117694923

Robinson, J. P., \& Godbey, G. (1997). True for life: The surprising ways Americans use their time. University Park, PA:

Pennsylvania State University Press.

Rowe, D. C., \& Gulley, B. L. (1992). Sibling effects on substance use and delinquency. Criminology, 30, 217-234. doi: $10.1111 / j .1745$ -

9125.1992.tb01103.x

Slomkowski, C., Rende, R., Conder, K. J., Simons, R. L., \& Conger, R. D. (2001). Sisters, brothers, and delinquency: Evaluating social influence during early and middle adolescence. Child Development, 72, 271-283.

Slomkowski, C., Rende, R., Novak, S., Lloyd-Richardson, E., \& Niaura, R. (2005). Sibling effects on smoking in adolescence: Evidence for social influence from a genetically informative design. Addiction, 100, 430-438. doi:10.1111/j.13600443.2004.00965.

Smetana, J. G., Robinson, J., \& Rote, W. M. (2015). Socialization in adolescence. In J. E. Grusec \& P. D. Hastings (Eds.), Handbook of socialization: Theory and research (pp. 6084). New York, NY: Guilford.

Smith, S. R., \& Hamon, R. R. (2012). Exploring Family Theories. New York, NY: Oxford University Press.

Trussell, D. E. (2014) Contradictory aspects of organized youth sport: Challenging and fostering sibling relationships and participation experiences. Youth \& Society, 46, 1-18. doi: 10.1177/0044118X12453058 
Ullrich-French, S., \& Smith, A. L. (2006).

Perceptions of relationships with parents and peers in youth sport:

Independent and combined prediction of motivational outcomes.

Psychology of Sport and Exercise, 7, 193-

214. doi:

10.1016/j.psychsport.2005.08.006

Updegraff, K. A., McHale, S. M.,

Whiteman, S. D., Thayer, S. M., \&

Delgado, M. Y. (2005). Adolescent

sibling relationships in Mexican

American families: Exploring the role of familism. Journal of Family

Psychology, 19, 512-522. doi:

10.1037/0893-3200.19.4.512

Weiss, M. R. \& Barber, H. (1995).

Socialization influences of collegiate

female athletes: A tale of two

decades. In Sex Roles, 33, 129-140.

Plenum: New York.

Whiteman, S. D., Bernard, J. M., \& McHale,

S. M. (2010). The nature and

correlates of sibling influence in two

-parent Aftrican American families.

Journal of Marriage and Family, 72, $267-$

281. doi: $10.1111 / \mathrm{i}-1741$ -

3737.2010.00698.

Whiteman, S. D., Jensen, A. C., \& Maggs, J.

L. (2013). Similarities in adolescent

siblings' substance use: Testing

competing pathways of influence.

Journal of Studies on Alcohol and Drugs,

74, 104-113. doi:

10.15288/jsad.2013.74.104

Whiteman, S. D., McHale, S. M., \& Crouter, A. C. (2007). Explaining sibling similarities: Perceptions of sibling influences. Journal of Youth and Adolescence, 36, 963-972. doi: 10.1007/s10964-006-9135-5

Whiteman, S. D., McHale, S. M., \& Soli, A. (2011). Theoretical perspectives on sibling relationships. Journal of Family Theory and Review. 3, 124-139. doi: 10.1111/j.1756-2589.2011.00087.x

Whiteman, S. D., Solmeyer, A. R., \& McHale, S. M. (2015). Sibling relationships and adolescent adjustment: Longitudinal associations in two-parent African American families. Journal of Youth and Adolescence, 44, 2042-2053. doi: 10.1007/s10964-015-086-0

Ziviani, J., Macdonald, D., Ward, H., Jenkins, D., \& Rogers, S. (2006). Physical activity and occupations of children: Perspectives of parent and children. Journal of Occupational Science, 13, 180-187. doi: 10.1080/14427591.2006.9726514 


\section{Tables}

Table 1

Results of multiple regression analysis examining the influence of mothers', fathers', and older siblings' interests in sports-related activities on younger siblings' interests controlling for structural and relational factors.

Variables

$B \quad S E b$

$\mathrm{B}$

Intercept

$3.38^{*}$

.10

Gender $.35^{* *}$

.11

Gender composition of sibling dyad $-.07$

.11

Youth-mother intimacy

$-.02^{\dagger}$

.02

Youth-father intimacy

$.02^{\dagger}$

.02

.14

Sibling intimacy

$.02^{*}$

.01

Mothers' interests in sports

$.18^{* *}$

.05

.23

Fathers' interests in sports

Older siblings' interests in sports

.09

.08

.08

$R^{2}$

$F$ for $R^{2}$

${ }^{\dagger} p<.10, * p<.05, * * p<.01, * * * p<.001$ 
Table 2

Results of multiple regression analysis examining the influence of mothers', fathers', and older siblings' skills in sports-related activities on younger siblings' skills controlling for structural and relational factors.

Variables

$B$

SE $b$

$\mathrm{B}$

Intercept

$3.13^{*}$

.10

Gender $.31^{* *}$

.11

Gender composition of sibling dyad

.02

.11

.01

Youth-mother intimacy

$-.02$

.02

$-.12$

Youth-father intimacy

.02

.02

Sibling intimacy

$.03^{* *}$

.01

Mothers' skills in sports

$.12^{\dagger}$

.06

.12

Fathers' skills in sports

$.18^{* *}$

.07

.17

Older siblings' skills in sports

$.26^{* * *}$

.07

.25

$R^{2}$

$F$ for $R^{2}$ $6.83^{* * *}$ 


\section{Table 3}

Results of multiple regression analysis examining the influence of mothers', fathers', and older siblings' time spent in sports-related activities on younger siblings' time spent in sports-related activities controlling for structural and relational factors and examining social learning bypotheses.

\begin{tabular}{|c|c|c|c|c|c|c|}
\hline \multirow[b]{2}{*}{ Variables } & \multicolumn{3}{|c|}{ Model 1} & \multicolumn{3}{|c|}{ Model 2} \\
\hline & $B$ & $S E b$ & $\beta$ & $b$ & $S E b$ & $\beta$ \\
\hline Intercept & $117.19^{* * *}$ & 24.37 & & $131.80^{* * *}$ & 24.24 & \\
\hline Gender & $88.00^{* *}$ & 27.92 & .22 & $60.93^{*}$ & 28.38 & .15 \\
\hline Gender composition of sibling dyad & -20.15 & 27.18 & -.05 & -27.62 & 26.75 & -.07 \\
\hline Youth-mother intimacy & -1.96 & 3.57 & -.04 & -2.56 & 3.52 & -.06 \\
\hline Youth-father intimacy & .11 & 3.74 & .00 & 1.80 & 3.71 & .04 \\
\hline Sibling intimacy & 3.28 & 2.58 & .10 & 2.212 & 2.57 & .06 \\
\hline Mothers' time spent in sports & .31 & .44 & .05 & .12 & .46 & .02 \\
\hline Fathers' time spent in sports & .34 & .21 & .11 & $.36^{\dagger}$ & .21 & .12 \\
\hline Older siblings' time spent in sports & $.24^{* * *}$ & .06 & .27 & $.44^{* * *}$ & .09 & .49 \\
\hline Mothers' time X youth-mother & & & & .02 & .11 & .01 \\
\hline \multicolumn{7}{|l|}{ intimacy } \\
\hline Fathers' time X youth-father & & & & $.08^{\dagger}$ & .05 & .12 \\
\hline \multicolumn{7}{|l|}{ intimacy } \\
\hline Older siblings' time $\mathrm{X}$ sibling & & & & -.01 & .01 & -.08 \\
\hline \multicolumn{7}{|l|}{ intimacy } \\
\hline Older siblings' time $\mathrm{X}$ gender & & & & $-.39^{* *}$ & .13 & -.31 \\
\hline \multicolumn{7}{|l|}{ composition } \\
\hline$R^{2}$ & & .17 & & & .23 & \\
\hline$F$ for change in $R^{2}$ & & $4.87^{* * *}$ & & & $3.16^{*}$ & \\
\hline
\end{tabular}

Journal of Amateur Sport Special Issue: Family Issues ～Osai \& Whiteman, 2017 


\section{Figures}

Figure 1

Association between older and younger siblings' participation in sports-related activities as a function of gender composition of the sibling dyad.

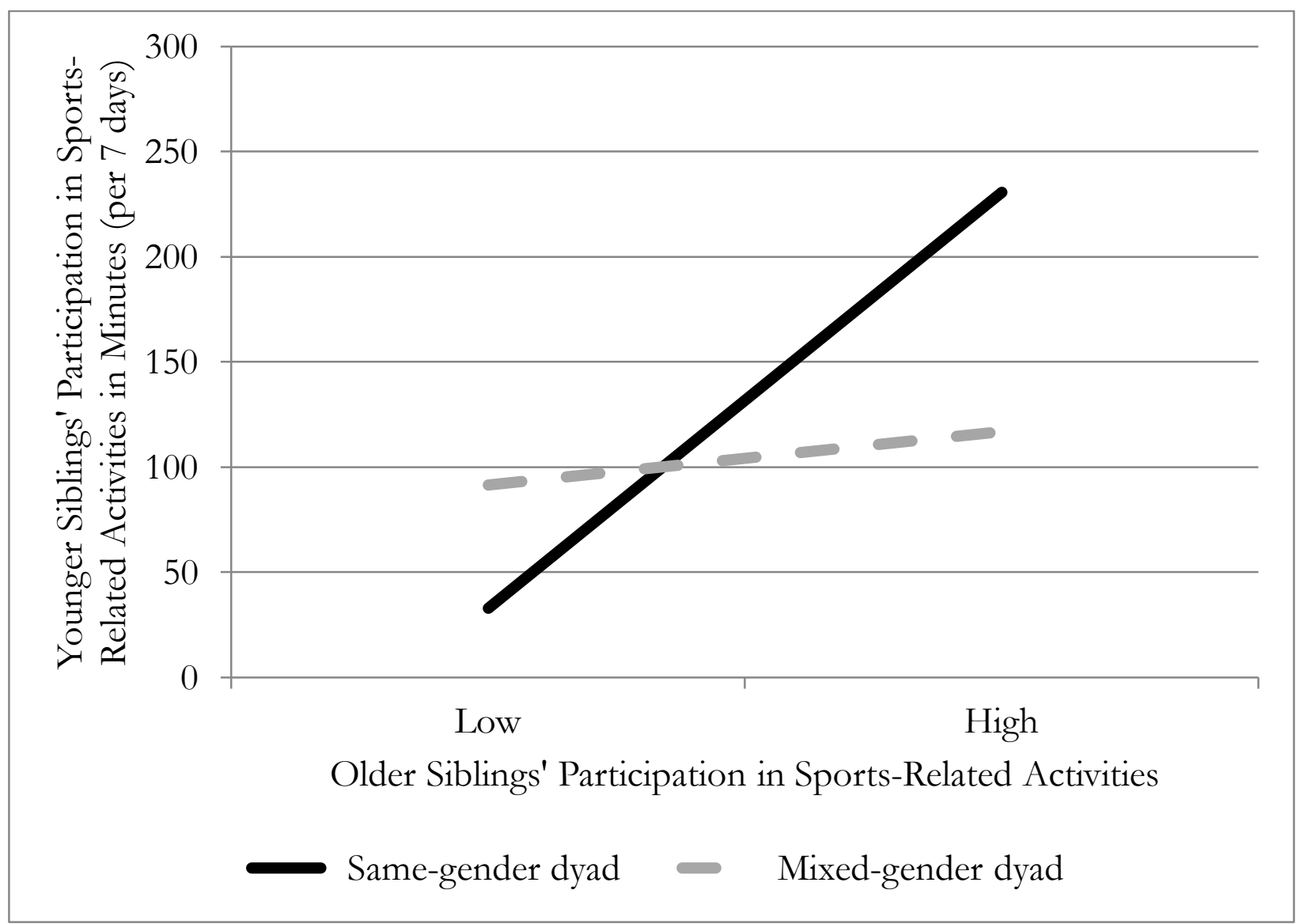

Journal of Amateur Sport Special Issue: Family Issues ～Osai \& Whiteman, 2017 